\title{
The Other Beetle-Hunter
}

\section{Citation}

Berry, Andrew, and Janet Browne. 2008. The other beetle-hunter. Nature 453: 1188-1190.

\section{Published Version}

http://dx.doi.org/10.1038/4531188a

\section{Permanent link}

http://nrs.harvard.edu/urn-3:HUL.InstRepos:3372266

\section{Terms of Use}

This article was downloaded from Harvard University's DASH repository, and is made available under the terms and conditions applicable to Other Posted Material, as set forth at http:// nrs.harvard.edu/urn-3:HUL.InstRepos:dash.current.terms-of-use\#LAA

\section{Share Your Story}

The Harvard community has made this article openly available.

Please share how this access benefits you. Submit a story.

\section{Accessibility}




\section{ESSAY}

\section{The other beetle-hunter}

\section{Thanks to a fateful letter, the theory of evolution by natural selection was unveiled 150 years ago this week. Andrew Berry and Janet Browne celebrate the letter's writer, Alfred Russel Wallace.}

( ne hundred years ago, to mark the 50 th anniversary of the reading of the original papers by Charles Darwin and Alfred Russel Wallace on evolution by natural selection, the Linnean Society of London issued its first Darwin-Wallace awards to honour contributors to the study of evolution. Six of the seven 1908 recipients, including Francis Galton, Ernst Haeckel and Joseph Dalton Hooker, received silver medals. The only gold medal ever awarded went to Alfred Russel Wallace. At 85, he had five years to live and three books still to publish.

Wallace, who usually avoided academic ceremony, came to London from his home in Dorset for the occasion. His speech on "Why did so many of the greatest intellects fail, while Darwin and myself hit upon the solution of this problem" is vintage Wallace, a mixture of self-deprecation and insight. His conclusion? "In early life both Darwin and myself became ardent beetle-hunters."

Wallace went on to play down his role in the announcement of evolutionary theory. Indeed, in one account of the 1908 celebrations, his presence - and his speech - was entirely overlooked. The botanist Joseph Hooker was instead fêted as the "sole survivor of those immediately concerned".

It is too easy to see Wallace as the 'other man' of evolutionary theory, the one who served merely as a stimulus to Darwin. Worse, he is often remembered as a crank whose later embrace of spiritualism and socialism muddied his biological thinking.

In fact, he was a superb scientist, whose contributions to many aspects of evolutionary biology and biogeography remain influential. His conduct in the evolution business is exemplary. Despite rumblings from conspiracy theorists that Darwin cheated him, Wallace got exactly what he wanted: scientific recognition. Darwin too got what he wanted: precedence. And the book that reinforced that precedence will justly be celebrated next year as the foundation of modern biology.

Neither man expected the joint announcement of evolution by natural selection at the Linnean Society in 1858. Indeed it was not as self-sacrificing an arrangement as is often portrayed. And it exemplifies what scientists have always known - that the making of a new theory rarely occurs in isolation. Rather, it depends on the support of colleagues, social networks and interactions within the scientific community, as well as the power of the theory itself.

\section{Humble beginnings}

Wallace was born in 1823 into a middle-class family in decline. After a minimal education he became an assistant to his brother, a railway surveyor. Trekking around the English countryside, surveying-pole in hand, he became interested in natural history. After a downturn in surveying, Wallace spent a year as a schoolteacher in Leicester. Here, in 1844, he met Henry Walter Bates, a 19-year-old with great expertise in natural history, especially beetles. Wallace duly became an "ardent beetle-hunter". That same year, Robert Chambers anonymously published his controversial, flawed and widely read theory of evolution, The Vestiges of the Natural History of Creation, in which he proposed a universal "law of development". Wallace regarded this an "ingenious hypothesis".

Inspired by Darwin's and Alexander von Humboldt's published accounts of their journeys, Wallace and Bates headed to the Amazon in 1848. They funded their travels by selling exotic specimens to museums and collectors. The contrast with Darwin's voyage is striking. Being of considerable independent means, Darwin travelled in some style on the Beagle as the captain's paying guest. Wallace and Bates had to work for a living, depended on the hospitality and assistance of locals, and needed an agent in London to market their wares.

Wallace returned from Brazil in 1852 after four years of exploration, collection and privation. The trip ended in disaster: he lost nearly all his specimens, and almost his life, when his ship caught fire in the mid-Atlantic. With nothing to show for all his efforts, his hope of joining the scientific élite was cruelly derailed. In 1854, he set off for Southeast Asia to do it all over again.

A year or so into these eastern travels, he was confident enough to write what he regarded as an evolutionary manifesto. "On the law which has regulated the introduction of new species" was published in 1855 in the Annals and Magazine of Natural History, a respected periodical read by both amateurs and professionals. Wallace pointed out that related species tend to occur together in both space and time - in the same geographical regions and in the same geological strata. The implication was clear to him: life consisted of a diversifying genealogical process. The paper was a major step towards the scientific status that Wallace craved, but it failed to create the stir he had hoped.

Around the start of 1856, geologist Charles Lyell told Darwin about Wallace's paper, warning Darwin that he might be scooped. Edward Blyth, an English naturalist in Calcutta, also wrote to Darwin: "Wallace has, I think, put the matter well; and according to his theory the various domestic races of animals have been fairly developed into species.” In May 1856, not especially worried about Wallace, Darwin began to write the long-planned tome he expected to call 'Natural Selection'. He opened a correspondence with Wallace, noting that Lyell and Blyth had drawn his attention to the paper and sympathizing over the apparent lack of scientific reaction: "very few naturalists care for anything beyond the mere description of species". Better still, Darwin wrote that he agreed with Wallace's conclusions. Wallace was thrilled. Here was a direct connection to a major star of the scientific firmament.

Wallace's 'law' was still only half a theory of evolution. In February 1858, during a bout of malaria, he glimpsed the other half: the missing mechanism. Recalling the writings of the economist Thomas Malthus, Wallace suddenly recognized that better-adapted groups would gradually replace less well-adapted ones. $\mathrm{He}$ waited anxiously for his fever to end so he "might at once make notes for a paper on the subject", which he entitled "On the tendency of varieties to depart indefinitely from the original type". He then did a surprising thing. Rather than submitting the paper directly to a journal, he sent it to Darwin. No one else had shown such interest in his work.

\section{A striking coincidence}

In June 1858 (the exact date is unknown), Darwin opened and read a brilliantly incisive handwritten essay that repeated most of his own account of evolution by natural selection. Late in the evening of 18 June 1858, he wrote to Lyell: "I never saw a more striking coincidence... if Wallace had my MS sketch written out in 1842 he could not have made a better short abstract!" Some Wallace scholars suggest that Darwin may have received this letter several weeks earlier and used the intervening period to polish his own ideas in the light of Wallace's. But the documentary record attests to the gradual formulation of 


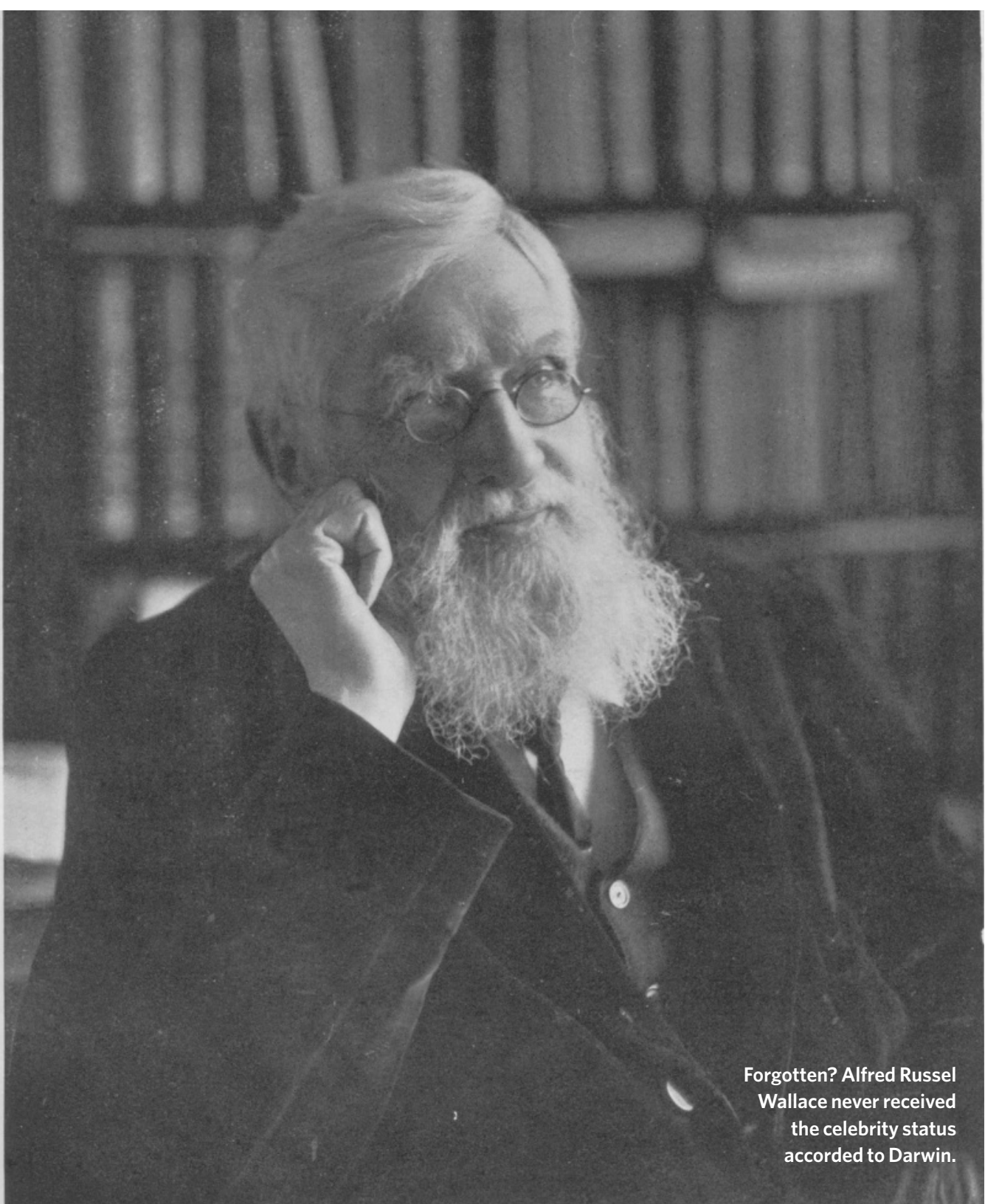

Darwin's theory over the previous 20 years. In particular, Darwin already had a clear understanding of evolutionary divergence, the main principle that some accuse him of taking from Wallace. Wallace was not telling Darwin anything he did not already know.

Publication was just as important to nineteenth-century science as it is now. Struggles over priority were fiery affairs that could make or break careers. Wallace's article was ready to be published - and as far as Darwin knew, it might already have been sent elsewhere for publication. As Lyell had predicted, he was forestalled. Gentlemanly honour required him to let Wallace take the credit. But Lyell and Hooker urged Darwin not to lose his claim as same idea. One hundred and fifty years ago this week, at a meeting on 1 July 1858, Lyell and Hooker communicated "On the tendency of species to form varieties; and on the perpetuation of varieties and species by natural means of selection" to the Linnean Society.

Neither author was present. Darwin was wretched with grief over the death of his youngest child from scarlet fever two days earlier, and Wallace was seriously ill at Dorey (now named Manokwari) in New Guinea.

When Wallace heard about the fate of his essay, he immediately wrote to Darwin and the others to say that he thought the arrangements were completely satisfactory. To his mother he wrote: "I have received letters from Mr. Darwin and Dr. Hooker, two of the most eminent naturalists in England, which has highly gratified me. I sent Mr. Darwin an essay on a subject on which he is now writing a great work. He showed it to Dr. Hooker and Sir C. Lyell, who thought so highly of it that they immediately read it before the Linnean Society. This assures me the acquaintance and assistance of these eminent men on my return home...."

Wallace had made it. Like Darwin, although by a more arduous route, Wallace had gone from 'ardent beetle-hunter' to scientific luminary. This shared collecting spirit provided a link that lasted even when their intellectual paths began to diverge.

The papers were published in the Linnean Society's journal in August 1858, while Wallace was travelling to Ternate in the Moluccas. Darwin was by then working on what would become Origin of Species. Contrary to the usual story, several people recognized the likely impact of the Linnean Society papers: the American botanist Asa Gray, a close friend of Hooker and Darwin, immediately mentioned in print the value of evolutionary theory for explaining patterns of plant distribution; and a young ornithologist at the University of Cambridge, Alfred Newton, sat up all night to master their proposals. That said, Thomas Bell, president of the Linnean Society, guaranteed himself an unfortunate footnote in the history books by writing in his annual review of 1858 : "The year which has passed has not, indeed, been marked by any of those striking discoveries which at once revolutionize, so to speak, the department of science on which they bear."

\section{A new science}

It took the Origin of Species to effect that revolution. One year later, with Darwin's book in his hands, Wallace was enthralled: "Mr. Darwin has given the world a new science," he wrote to his friend George Silk, adding that "his name should stand above that of every philosopher of ancient or modern times. The 
force of admiration can no further go!!!”

So why has the name of one so prescient, and so generous, faded from popular view, while it still inspires those who find the modern infatuation with Darwin stultifying?

Exploring Wallace's role in the evolutionary story reveals a host of other figures who also deserve to be heard. Over the past twenty years, the Darwinian revolution has been shown to be neither a revolution as commonly understood nor solely due to Darwin. Many people proposed developmental schemes, some as famous as Jean-Baptiste Lamarck and Herbert Spencer, others relatively unknown but just as interesting. To remember Wallace is therefore to recognize that "evolution was in the air", and prompts one to wonder how Darwin's name rose so smoothly to the top.

The structure of science plays a part. First, the scientific community and the public tend to see science as a succession of advancing steps, each achieved by a named individual. In this view, precedence is everything: posterity ignores the second placed. Second, major changes in scientific theory are not just about the formulation of new ideas, but also depend on circulation and discussion. Shortly after Darwin's book was published, the word 'darwinism' began appearing in reviews and articles, and quickly came to denote an intellectual movement that also drew on the work of other figures, including Spencer, Chambers, Thomas Henry Huxley and Haeckel, as well as Wallace. Darwin's Origin of Species, and Darwin himself, became the flag to which many radical ideas rallied.

Perhaps Wallace contributed to his own eclipse too. For instance, he called one of his finest books Darwinism. Darwin's publishing strategy after Origin of Species was to consolidate, producing ever more evidence in support of the theory. Wallace, meanwhile, published on myriad topics, from the true identity of Shakespeare to the advisability of railway labour strikes. Darwin's politics, although strongly felt, had few public airings. Wallace, in contrast, was an outspoken socialist, the campaigning president of the Land Nationalisation Society, which insisted that private ownership of land was the root of all social iniquity. Attracted to radical issues, he became a spiritualist, believed in phrenology as "the true science of mind", and was a leading opponent of smallpox vaccination. This undermined his credibility with many scientists. Some defenders of Wallace consider him a victim of the Victorian class system, but his problems stem from more than a humble background. After all, Huxley, Darwin's most prominent advocate,

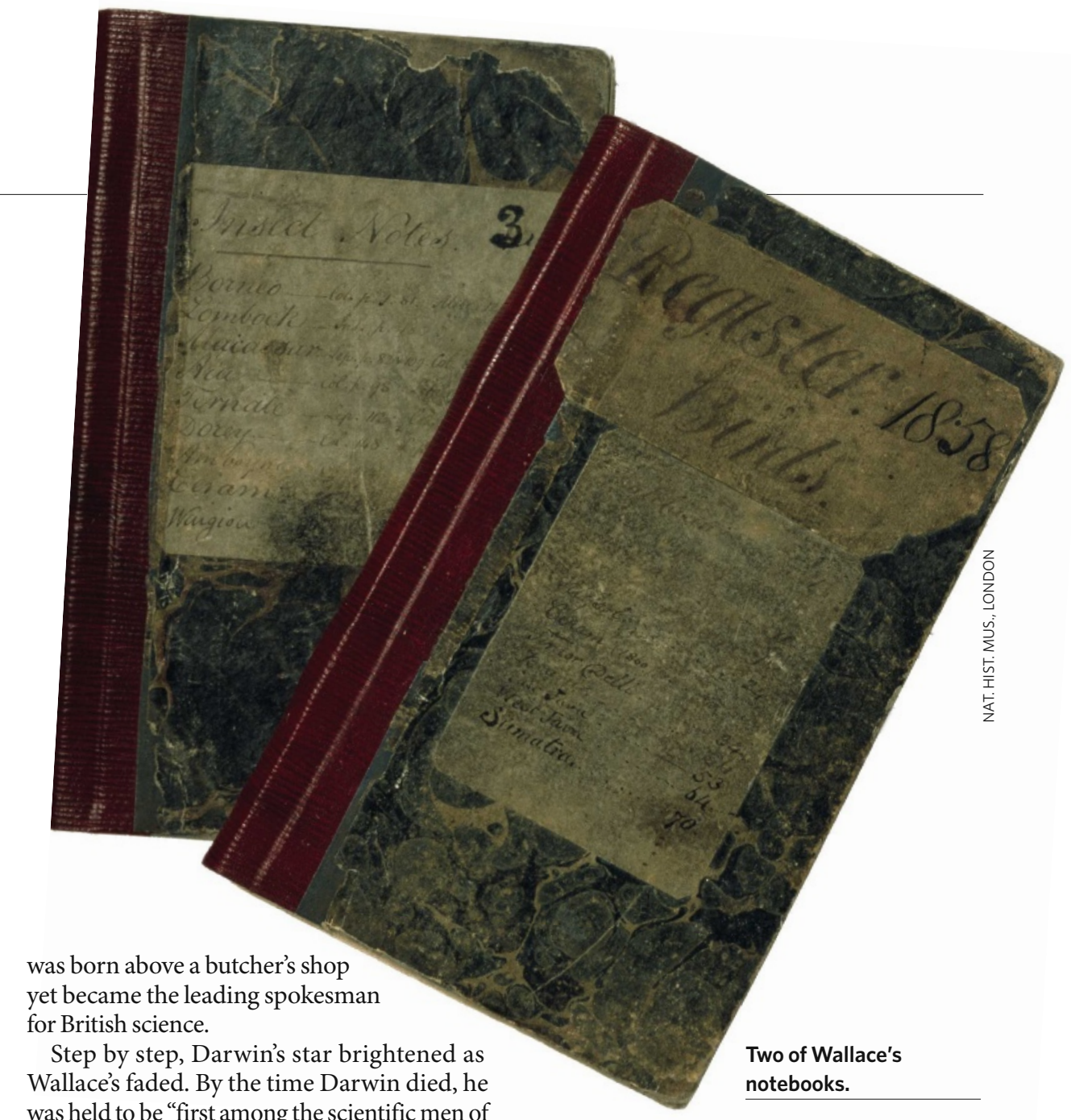

was held to be "first among the scientific men of England", as the socialist writer Edward Aveling put it. Darwin's name was inextricably linked with the idea of evolution and with broader shifts in public opinion that swept through the nineteenth century. Wallace never acquired Darwin's celebrity status. Unlike Darwin, he was not buried in Westminster Abbey, although a wall medallion was unveiled there in 1915 , two years after his death. None of his houses became a museum. Images of Wallace did not appear in any of the satires or cartoons of evolution. Nor did Wallace have the evocative connection that Darwin did to the Galapagos Islands. His manuscripts were not published, and his library was not preserved.

At the start of the twenty-first century, Darwin could hardly be more prominent. His name is invoked in every modern discussion of evolution. He stares out from websites both for and against evolutionary theory. Books, stamps, exhibitions, conferences, festivals and artistic works abound. A portrait of Darwin was commissioned in 1881 by the Linnean Society from the artist John Collier, and copied for the National Portrait Gallery, the Royal Society and the Darwin Museum at Down House. By contrast, the portrait of Wallace that hangs in the
Linnean Society was not painted until 1998.

Wallace modestly endorsed these differences. In a letter in 1869, he compared Darwin to a great military general who kept sight of every campaign detail, and likened himself to a guerrilla, useful for a skirmish. "I feel truly thankful that Darwin had been studying the subject so many years before me, and that I was not left to attempt and to fail, in the great work he has so admirably performed."

As for the events of 150 years ago, Erasmus Darwin, Charles's older brother, encapsulated Wallace's magnanimity when he wrote in 1871 to Charles's daughter Henrietta: "in future histories of science the Wallace-Darwin episode will form one of the few bright points among rival claimants."

Andrew Berry is lecturer on biology at Harvard University, Biology Laboratories, 16 Divinity Avenue, Cambridge, Massachusetts 02138, USA, and is editor of an annotated anthology of Wallace's writings, Infinite Tropics.

Janet Browne is Aramont professor of the history of science, Department of the History of Science, Harvard University, Science Center 371, Cambridge, Massachusetts 02138, USA. She is the author of a two-volume biography of Darwin and of Darwin's "Origin of Species": A Biography.

See http://tinyurl.com/5beghd for further reading. 